University of Nebraska - Lincoln

DigitalCommons@University of Nebraska - Lincoln

Papers in the Earth and Atmospheric Sciences

Earth and Atmospheric Sciences, Department

\title{
Paleocene Cyclic Sedimentation in the Western North Atlantic, ODP Site 1051, Blake Nose
}

\author{
Mary Anne Holmes \\ University of Nebraska-Lincoln, mholmes2@unl.edu \\ David K. Watkins \\ University of Nebraska-Lincoln, dwatkins1@unl.edu \\ Richard D. Norris \\ Scripps Institution of Oceanography, rnorris@ucsd.edu
}

Follow this and additional works at: https://digitalcommons.unl.edu/geosciencefacpub

Part of the Earth Sciences Commons

\begin{abstract}
Holmes, Mary Anne; Watkins, David K.; and Norris, Richard D., "Paleocene Cyclic Sedimentation in the Western North Atlantic, ODP Site 1051, Blake Nose" (2004). Papers in the Earth and Atmospheric Sciences. 72.

https://digitalcommons.unl.edu/geosciencefacpub/72
\end{abstract}

This Article is brought to you for free and open access by the Earth and Atmospheric Sciences, Department of at DigitalCommons@University of Nebraska - Lincoln. It has been accepted for inclusion in Papers in the Earth and Atmospheric Sciences by an authorized administrator of DigitalCommons@University of Nebraska - Lincoln. 
Published in Marine Geology 209 (2004) 31-43. Copyright 2004, Elsevier. ISSN: 0025-3227. DOI:

10.1016/j.margeo.2004.06.005. Used by permission. http://www.elsevier.com/locate/margeo

\title{
Paleocene Cyclic Sedimentation in the Western North Atlantic, ODP Site 1051, Blake Nose
}

\author{
Mary Anne Holmes ${ }^{a}$, David K. Watkins ${ }^{a}$, Richard D. Norris ${ }^{b}$ \\ ${ }^{a}$ Geosciences Department, University of Nebraska-Lincoln, Lincoln, NE, USA \\ (mholmes2@unl.edu; dwatkins1@unl.edu) \\ b Scripps Institution of Oceanography, UCSD, La Jolla, CA, USA (RNorris@ucsd.edu)
}

\begin{abstract}
Upper Paleocene (zone CP8b) cyclic sediment from Ocean Drilling Program (ODP) Site 1051 on Blake Nose, western North Atlantic, alternates from white carbonate-rich to green carbonate-poor in response to precessional forcing. Compositional differences between the two bed types are minor: mineral and nannofossil composition of the beds vary subtly, but grain size of the terrigenous component and biogenic silica content remain constant. Iron content determined by sediment magnetic susceptibility and iron intensity determined by a core-scanning XRF correlates negatively with carbonate content and are higher in green beds. Kaolinite content of green beds is slightly higher as well. Green beds exhibit lower evenness values than white beds for nannofossil assemblages and are more dominated by the species Coccolithus. Dominance by Coccolithus indicates more mesotrophic conditions over Blake Nose during deposition of the green beds, which correlates with slightly higher iron and kaolinite contents.

The absence of change in terrigenous grain size and the absence of any indication of planktonic blooms indicate that there was a minor, most likely eolian, input of iron and kaolinite during deposition of the green beds. The source area was most likely northwest Africa, which supplied iron and kaolinite when source areas deflated under drier conditions. With this scenario, kaolinite is an indicator of drier climate and source area erosion, rather than the warmer and/or wetter conditions under which it forms in soils.

During precessional minima or perihelion summer (the opposite of our current configuration), there was an increased range of seasonal temperatures and an increase in the intensity of summer and winter monsoon circulation. As a consequence, there was more rainfall in northern Africa and drier conditions in the continental interiors at mid-latitudes. Green bed deposition occurred during precessional maxima when the North Atlantic was cooler, northwest Africa drier, and the eolian flux to the western North Atlantic slightly increased.
\end{abstract}

Keywords: cyclic sedimentation; Paleocene; North Atlantic; kaolinite; magnetic susceptibility

Received December 16, 2002; received in revised form June 8, 2004; accepted June 8, 2004.

\section{Introduction}

Cyclic sediments are often interpreted as "Milankovitch-driven," but the exact cause- and-effect relationship between orbital variation and the specific sedimentary process(es) being forced is not always clear. Wind directions and strengths change, rainfall varies, oceanic cur- 
rents and atmospheric pressure systems shift as the Earth's orbit varies. The specific process that effects change in sedimentation will depend on the location and the time period involved. Various workers have been able to connect specific sedimentary processes with Milankovitch cyclicity, mostly in Pleistocene and/or Holocene sediment. Mineralogic variations can be attributed to a specific sedimentary cause. For example, Liu et al. (2003) demonstrated a cyclical clay mineral variation with glacial-interglacial conditions in sediment deposited over the last 2 million years in the South China Sea. They attributed clay mineral variation to cyclical changes in the intensity of summer as opposed to winter East Asian monsoons. During glacial stages when the winter monsoon was enhanced, the Taiwan and Yangtze Rivers contributed illite and chlorite and the Pearl River contributed kaolinite because stronger northerly currents transported these fluvially derived clay minerals to the South China Sea. Luzon and Indonesia contributed smectite and mixed-layer clay minerals during interglacials when the summer monsoon was enhanced and ocean currents transported more clay smectite and mixed-layer clay minerals from the south. In another example, Kuhn and Diekmann (2002) found that variations in ocean currents with glacial/interglacial stages over the last $590 \mathrm{ky}$ produced variations in the ratio of kaolinite to chlorite in sediment at Ocean Drilling Program (ODP) Site 1089 in the southern Cape Basin. During glacial periods, more chlorite was transported to the site via the Circumpolar Deep Water Current, and during interglacial periods, more kaolinite was transported to the site via the Agulhaus and North Atlantic Deep Water currents. Foucault and Mélières (2000) found alternating dominance of marine sediment by palygorskite and kaolinite or smectite in precession-driven cyclic Pliocene sediment from outcrop and submarine sections in the Mediterranean. High levels of palygorskite and kaolinite were supplied by the wind during dry periods on the northern African continent.

Behl et al. (2000) found a variation in grain size of sediment that corresponds to Milankovitchband cyclicity in Holocene sediment from ODP Site 1017 on the southern slope of the Santa Lu- cia Bank, central California margin and linked this variation to cyclic changes in the efficiency of off-shelf transport, but could not specify how variations in bottom current strength may have contributed to the grain-size variation.

Variations in primary productivity have also been observed. Wendler et al. (2002) related midCenomanian precession-controlled marl/chalk couplets in the Anglo-Paris Basin to variations in water column stratification based on calcareous dinoflagellate cysts. Waterhouse (1995) found eccentricity-induced variations in the palynofacies of the Jurassic Kimmeridge Clay of Dorset, UK, which indicate cyclic changes in the strength of marine currents.

Arthur and Dean (1991) studied geochemical indicators in Cretaceous cyclic marl/chalk of the Atlantic and the Western Interior Seaway of North America (Greenhorn and Niobrara Formations). They attributed alternations of marl/ chalk to result from three cyclic alternations in sedimentary processes: (1) biogenic productivity resulting from variations in surface salinity or upwelling, (2) variations in freshwater runoff and terrigenous flux, and/or (3) water column stability and bottom-water production and circulation, which affected preservation as well as accumulation of organic components.

A difficulty in determining what sedimentary process varies to produce cyclic sediments is that when a principal component varies, other components vary by dilution. For the present study, we take a multi-fold approach to uncovering the sedimentary processes affected by precession-forced cyclicity in Upper Paleocene sediment from the Blake Nose in the western North Atlantic by studying separate biogenic and terrigenous components as well as stable carbon and oxygen isotope composition of the whole rock. One hundred eighty meters of moderately bioturbated Upper Paleocene sediment recovered from Blake Nose off the east coast of Florida at ODP Site 1051 (Figure 1) varies cyclically from green to white. Compared to white beds, green beds have lower carbonate and higher iron content as indicated by both magnetic susceptibility values and iron intensity, the latter determined by an X-ray fluorescence core scanner (Shipboard Scientific Party, 1998; Norris and Röhl, 1999; 


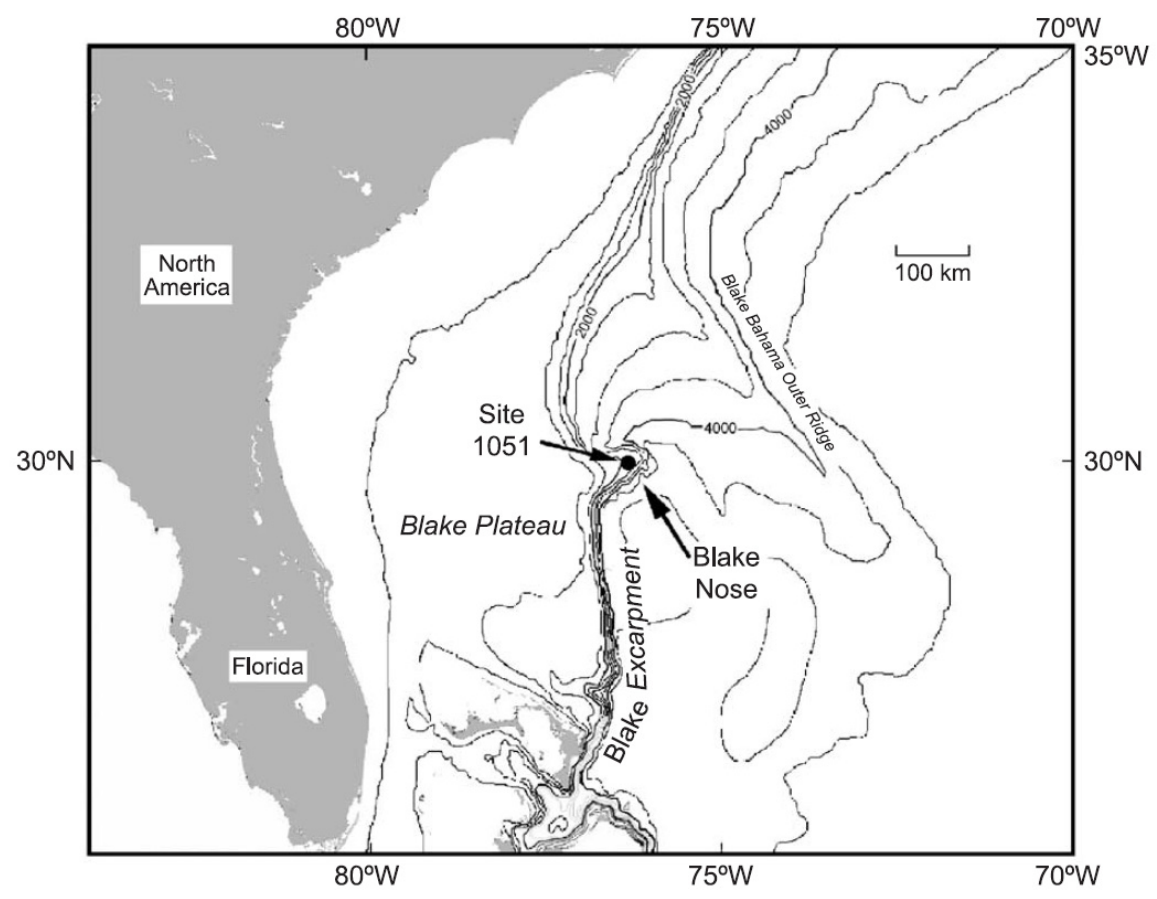

Fig. 1. Location of Site 1051 on Blake Nose, western North Atlantic.

Röhl et al., 2000). The cycle duration is 20-21 ky, near the modern mean precession average of the 23- and 19-ky bands (Norris and Röhl, 1999).

This sediment was deposited in an intermediate water mass at nearly 2,000-m water depth, $350 \mathrm{~km}$ from the present shoreline, in a hemipelagic to pelagic setting. Shipboard examination of the sediment as smear slides failed to reveal any difference in biogenic silica content, terrigenous grain size or composition, or composition of the carbonate (dominantly coccoliths with minor foraminifers), nor could it be determined using smear slide analysis whether carbonate or iron deposition alone varied, or both co-varied. Down-slope processes are evident in sediment above and below this interval as folded (slumped) bedding, but the lack of grain-size variation within any bed of the cyclic interval indicates that none of the beds are turbidites.

The aim of the present study is to analyze separate components of cyclic sediments to determine which components vary cyclicallyand to interpret from these what sedimentary process varied at aprecessional beat to produce alternating green/white carbonate-rich beds in the western North Atlantic.

\section{Methods}

\subsection{Laboratory Methods}

Sixty samples were taken at 5-cm intervals over a 3-m section of core from Hole 1051B to sample a minimum of ten cycles of white-green sedimentation (Figure 2). Carbonate was determined on a sample split by the bomb method (Mueller and Gastner, 1971). Stable isotopes of carbon and oxygen were determined on sample splits at Woods Hole Oceanographic Institution. Another sample split was used for terrigenous grain size and mineral composition determination after carbonate was removed by the buffered acetate method of Jackson (1969). A Coulter Counter was used for grain-size analysis. The remainder of this split had the less than 2-Am fraction separated and mounted via filtration as oriented mounts for X-ray diffraction analysis (Pollastro, 1982) using a Scintag PAD V X-ray diffractometer equipped with a $\mathrm{Cu} \mathrm{Ka} \mathrm{X}$-ray tube and a graphite monochromator. Clay minerals were identified following Brown and Brindley (1980) and Moore and Reynolds (1997). Peak positions and sizes were determined using the ProfileFit program of Scintag's Vax-based DMS software, 


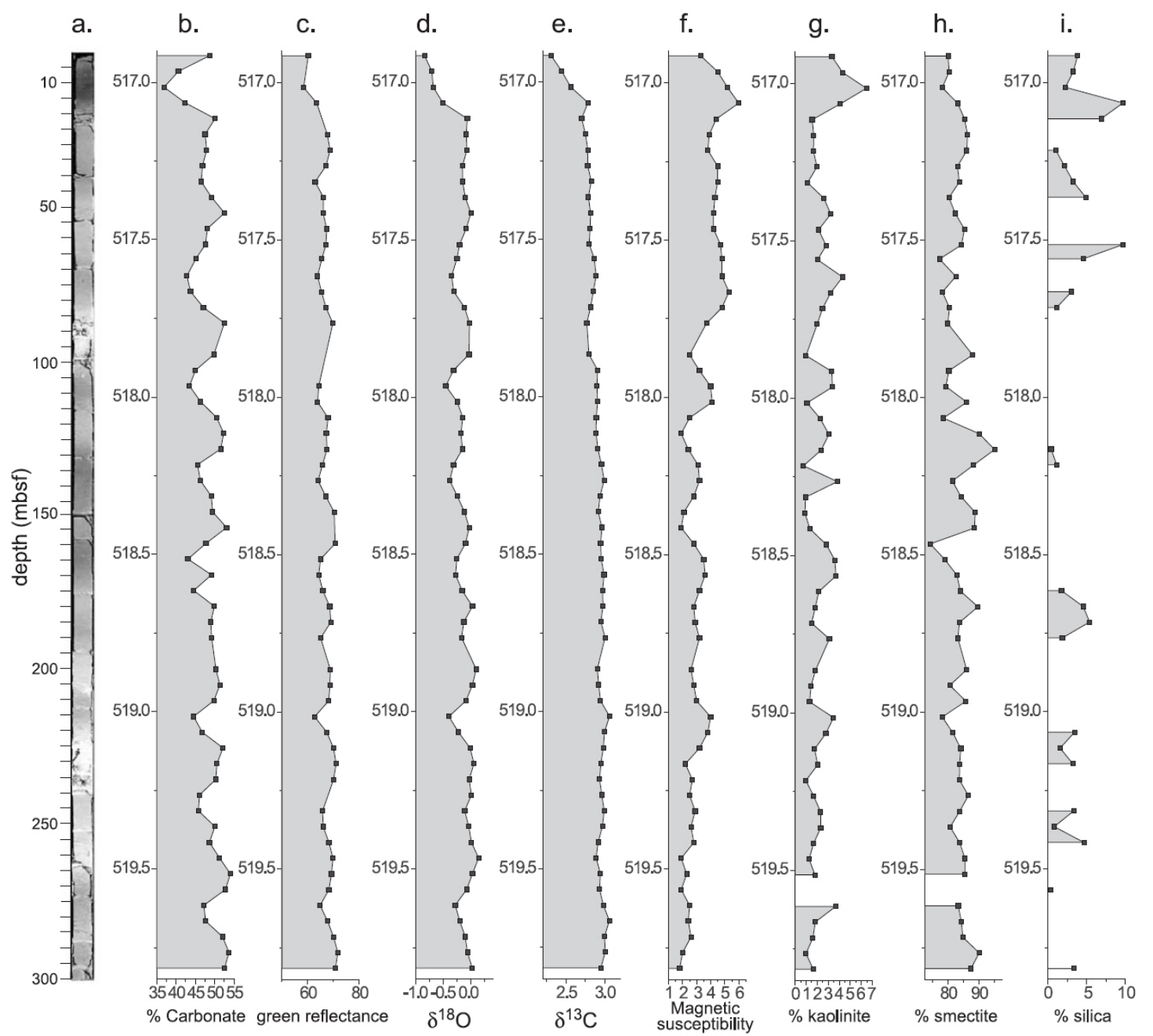

Fig. 2. Proportion of components in the examined interval. (a) Photograph of the core showing the subtle alternation between darker, green intervals and lighter, white intervals; (b) percent carbonate; (c) green $\left(450 \mathrm{~nm}\right.$ ) reflectance; (d) $\delta^{18} \mathrm{O}$ of bulk sediment; (e) $\delta^{13} \mathrm{C}$ of bulk sediment; (f) magnetic susceptibility; (g) percent kaolinite in the $<2-\mu \mathrm{m}$ fraction; (h) percent smectite in the $<2-\mu \mathrm{m}$ fraction; (i) percent biogenic silica in selected samples.

using a split Pearson, unweighted curve fit. Proportions of clay minerals were calculated using the three peak areas summed to $100 \%$, with 10:17 A I/S clay given a weighting of 0.5 , illite a weighting of 2.5 , and kaolinite a weighting of 1.0 (Biscaye, 1965). Chlorite was not found. Ten percent of the samples were run in triplicate to assess repeatability of the semi-quantitative method. Repeatability is better for minor com- ponents and averaged $0.5 \%$ for kaolinite (range: 0-1\%), and 3\% each for 10:17 $\AA$ I/S clay and illite estimates.

Biogenic silica was determined using the sequential alkaline extraction method of DeMaster (1981, 1991) and Conley and Shelske (1993) and run in triplicates. However, a high sponge spicule content of some samples gave questionable results for those samples. Silica data are reported 
only for repeatable amounts of silica extracted over time. In addition, diatoms were separated, identified, and counts of 400 individual species were made. Magnetic susceptibility and color reflectance values were determined shipboard (Shipboard Scientific Party, 1998). Magnetic susceptibility was determined using a Bartington MS2 meter with an 8-cm diameter loop (Shipboard Scientific Party, 1998, p. 36). The dominant contributor to the magnetic susceptibility signal is magnetite, with minor and nonsystematic contributions from iron-rich clays and iron sulfides (Ogg and Bardot, 2000). Color was measured at $5 \mathrm{~cm}$ intervals using a Minolta CM-2002 spectrophotometer, which returns Munsell color codes and reflectance in thirty-one 10-nm-wide bands of the visible spectrum (Shipboard Scientific Party, 1998, p. 14).

Calcareous nanofossils census data were derived from smear slides prepared using a double suspension method. In this method, a sediment-water suspension is fully dried on a cover glass, and then re-suspended in just enough water to form a liquid slurry. This slurry is smeared over the cover slide and rapidly dried. This double suspension method permits a thorough dispersion of the material while preventing size (or shape) fractionation on the slide. Multiple population counts from single test slides indicated no distributional bias due to nanofossil size or shape (confidence interval $>99.99 \%$ ). Counts of 456 specimens per sample were conducted to determine the percentage of all taxa. This census number was chosen because it insures that the maximized second standard deviation of the percentage estimate will be within $5 \%$ of the actual proportion at the $95 \%$ confidence interval (Chang, 1967). Data are in the appendix. Census counts were made using a Zeiss Photoscope II at 1250 $\times$ magnification. Rock samples and smear slides are housed within the collections of the ODP Micropaleontological Reference Center at the University of Nebraska State Museum (UNSM).

\subsection{Statistical Analysis}

Pearson correlation coefficients were calculated for all variables using Systat v. 10 software. Spectral analysis was performed on variables that showed no correlation with depth using Fast Fourier Transform (FFT) in Origin v. 6.0 software. Components that vary with depth were untrended for FFT analysis by subtracting predicted values from regression equations calculated with Origin v. 6.0 software. This technique eliminated a large 3-m cycle (length of the sampled interval) and allowed any cycle(s) not indicative of an upsection trend to emerge. Significance of spectral power was determined using the method of Davis (1986).

\section{Results}

\subsection{Distribution of Components}

\subsubsection{Sediment Composition}

Sediment cycles are recognized by color variation (Figure 2a and c) from green (2GY 6/1) to white (3GY 7/1). Carbonate, composed predominantly of nanofossils with minor foraminifers, is significantly higher in white (50-55\%), and lower $(40-45 \%)$ in green beds (Figure 2b; Table 2). Carbonate content tends to decrease upsection over the interval (Table 1, $r=0.447 ; n=59$ ). Carbonate exhibits a $27-\mathrm{cm}$ cyclicity that is significant at the $94 \%$ confidence level (untrended data, Figure 3a). Green color (Figure 2c) becomes less intense upsection (Table $1 ; r=0.520$ ) and, like calcite, exhibits a $27-\mathrm{cm}$ cyclicity $(99.4 \%$ confidence level; Figure 3b). Bulk sediment oxygen isotope values $\left(\delta^{18} \mathrm{O}\right)$ vary from $-0.84 x$ to $+0.14 x$ (Figure $2 \mathrm{~d}$ ) and correlate with carbonate content (Table $1, r=0.703)$. There is a statistically significantly more negative $\delta^{18} \mathrm{O}$ signal in the green beds than in the white beds (Table 2). Bulk sediment d13C values vary from $2.30 \%$ to $3.06 \%$ and decrease upsection (Figure 2e and Table 1, $r=0.747 ; n=$ 59). $\mathrm{C}$ and $\mathrm{O}$ isotopes values are higher for more carbonate-rich beds (Table 1), but the differences are not strong enough for either isotope to have

Table 1

Correlation coefficients for selected sediment components $(n=59)$

\begin{tabular}{llll}
\hline & Depth $^{\mathrm{a}}$ & $\delta^{18} \mathrm{O}^{\mathrm{b}}$ & Magnetic susceptibility \\
\hline Calcite & 0.447 & 0.703 & \\
Green $^{\mathrm{c}}$ & 0.520 & & \\
$\delta^{13} \mathrm{C}$ & & 0.707 & -0.520 \\
\hline
\end{tabular}

${ }^{\mathrm{a}}$ Depth of sample in core.

${ }^{\mathrm{b}}$ Isotope measurements are on bulk sample.

${ }^{\mathrm{c}}$ Green is reflectance value measured by spectrophotometer (green-ness of sediment). 
a.

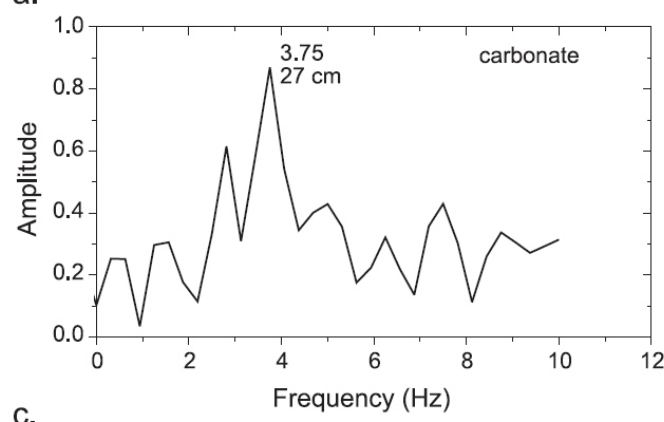

c.

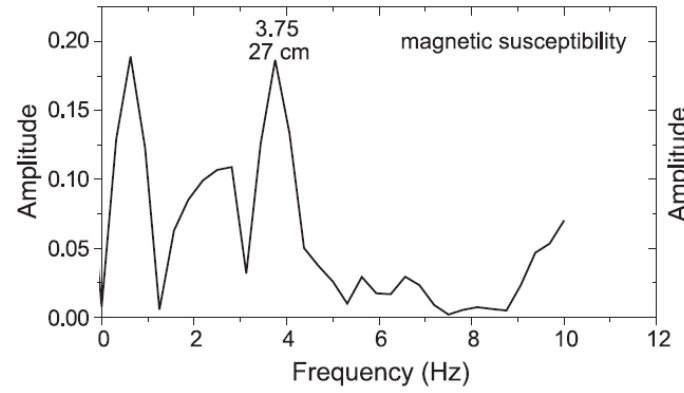

b.

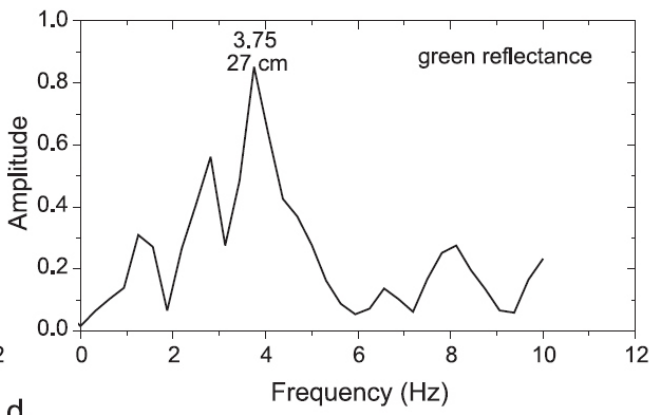

d.

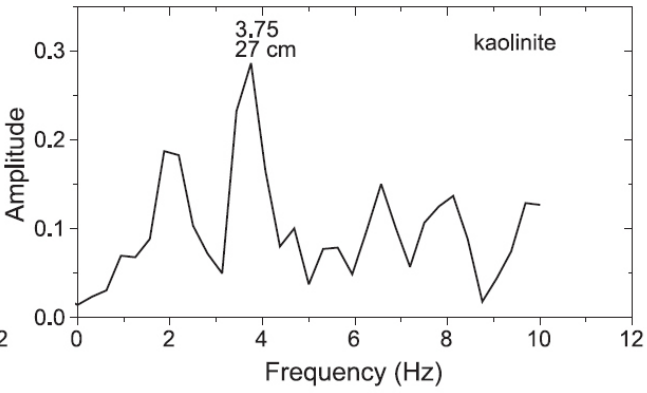

Fig. 3. Results of FFT analysis for components that shows a significant spectral power for $27 \mathrm{~cm}$. (a) Carbonate; (b) green (450 nm) reflectance; (c) magnetic susceptibility; (d) percent kaolinite in the $<2-\mu \mathrm{m}$ fraction. No other spectral power peaks were significant. The peak at $0.6 \mathrm{~Hz}$ for magnetic susceptibility, $1.6 \mathrm{~m}$, exceeds the Nyquist frequency for sample spacing and therefore is not significant.

significant power. Two other components exhibit a 27-cm cyclicity: (1) magnetic susceptibility (91\% confidence level; Figure 3c), which increases upsection (Figure 2f), and (2) kaolinite (94\% confidence level; Figure 3d), which varies from $<1 \%$ to $6.5 \%$ and decreases upsection (Figure $2 \mathrm{~g}$ ). Magnetic susceptibility also has a power at $1.6 \mathrm{~m}$ (Figure 3c), but this spacing is greater than $1 / 4$ the sampled interval (i.e., exceeds the Nyquist frequency), and thus is not significant.

Table 2

Compositional differences between green and white beds

\begin{tabular}{|c|c|c|c|}
\hline \multirow[t]{2}{*}{ Component } & \multirow{2}{*}{$\frac{\text { White beds }}{n=36}$} & \multirow{2}{*}{$\frac{\text { Green beds }}{n=22}$} & \multirow{2}{*}{$\begin{array}{l}\text { Confidence } \\
\text { level } \\
(\%)\end{array}$} \\
\hline & & & \\
\hline Calcite & $49.9 \%$ & $45.9 \%$ & $>99.9$ \\
\hline$\delta^{18} \mathrm{O}$ & -0.074 & -0.291 & $>99.9$ \\
\hline 10:17 $\AA$ clay & $84.7 \%$ & $81.8 \%$ & 99.5 \\
\hline Kaolinite & $1.8 \%$ & $3.0 \%$ & 99.9 \\
\hline Magnetic susceptibility & 2.96 & 3.88 & 99.9 \\
\hline Discoaster spp. & $26 \%$ & $20 \%$ & 93.0 \\
\hline
\end{tabular}

To verify the variation of kaolinite content and to overcome the problem of closure with clay mineral data summed to $100 \%$, the ratio of kaolinite peak area to smectite (10:17 $\AA \mathrm{I} / \mathrm{S}$ clay) peak area $(\mathrm{K} / \mathrm{S}$ ratio) was calculated. $\mathrm{K} / \mathrm{S}$ ratios also correlate negatively with carbonate $(r=-0.640$; $n=59)$. They do exhibit a $27-\mathrm{cm}$ power, but it is not statistically significant. $R=0$ 10:17 $\AA$ I/S clay (i.e., randomly interstratified illite/smectite) varies from $75 \%$ to $95 \%$ of the $<2-\mu \mathrm{m}$ fraction (Figure $2 \mathrm{~h}$ ) and has $10 \%$ to $20 \% 10 \AA$ layers. There is no systematic change in percentage of the $10 \AA$ layers with depth, indicating that burial diagenesis plays no role in clay mineral composition. Illite comprises $3 \%$ to $23 \%$ of the clay-size fraction. Neither $R=0$ 10:17 $\AA$ I/S clay nor illite exhibits cyclic distribution. Green beds have more kaolinite and higher magnetic susceptibility (Table 2 ). There is also a higher illite content in green beds, but the correlation between illite and color is not strong, so that illite exhibits no significant power. Biogenic silica ranges from $<1 \%$ to $10 \%$ (Figure $2 \mathrm{i}$ ). It shows no overall trend with 
depth and does not correlate with any other major component. No diatom species exhibited cyclicity in abundance.

\subsubsection{Sediment Grain Size (Carbonate-Free Frac- tion)}

Mean grain size of the carbonate-free fraction varies from 17 to $29 \mu \mathrm{m}$ (with one value at 40 $\mu \mathrm{m}$, Figure $4 \mathrm{a})$. Mean grain size shows no trend upsection and exhibits no cyclicity. Within any green bed, mean grain size either increases upward or shows no trend. Within any white bed, mean grain size varies randomly. Median grain size varies from 9.7 to $13.5 \mu \mathrm{m}$ (Figure $4 \mathrm{~b}$ ) and exhibits no cyclicity. The mode varies little with depth and ranges from 10 to 16 Am (Figure 4c). All samples are moderately sorted (Figure 4d). The 3- to 6- $\mu \mathrm{m}$ size fraction (fines) and the 24to $100-\mu \mathrm{m}$ fraction (intermediates) behave coherently and are grouped together for discussion. The fines range from $30 \%$ to $40 \%$ of the carbonate-free fraction (Figure 4e). They show no trend upsection and exhibit no cyclicity. The intermediate size grains range from $25 \%$ to $40 \%$ of the carbonate-free fraction (Figure $4 \mathrm{f}$ ). They tend to increase upsection and exhibit no cyclicity. The a.

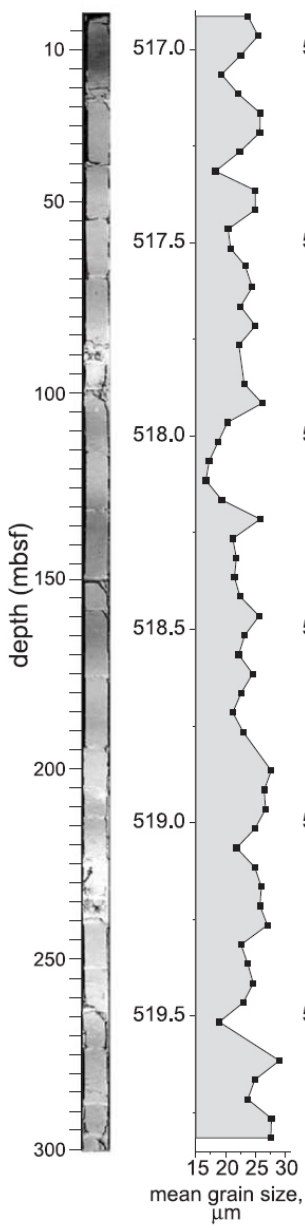

b.
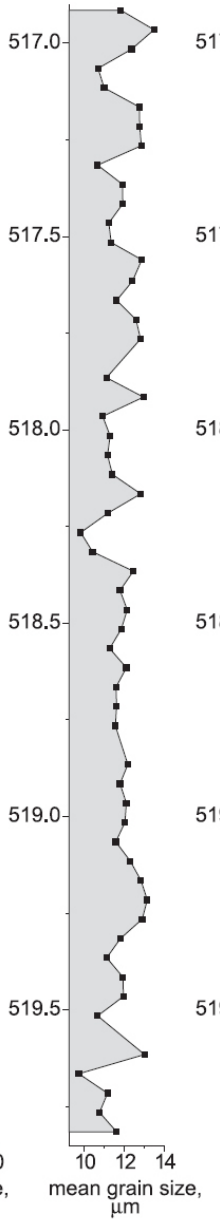

C.

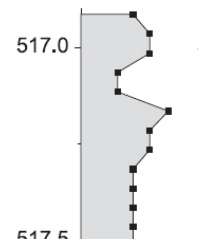

d.

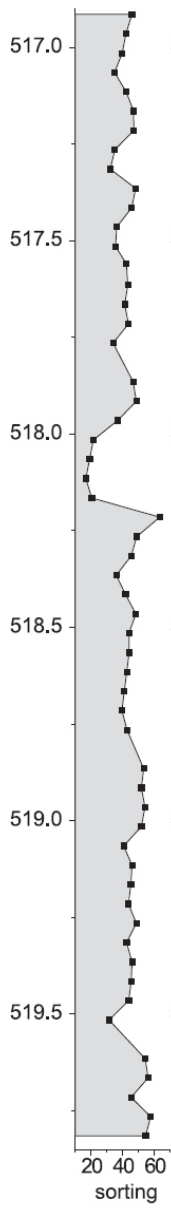

e.

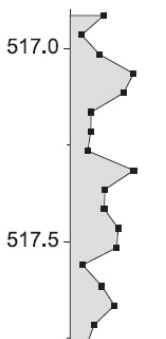

f.

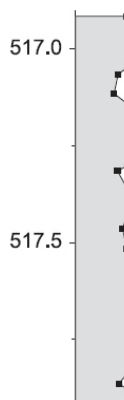

518.0
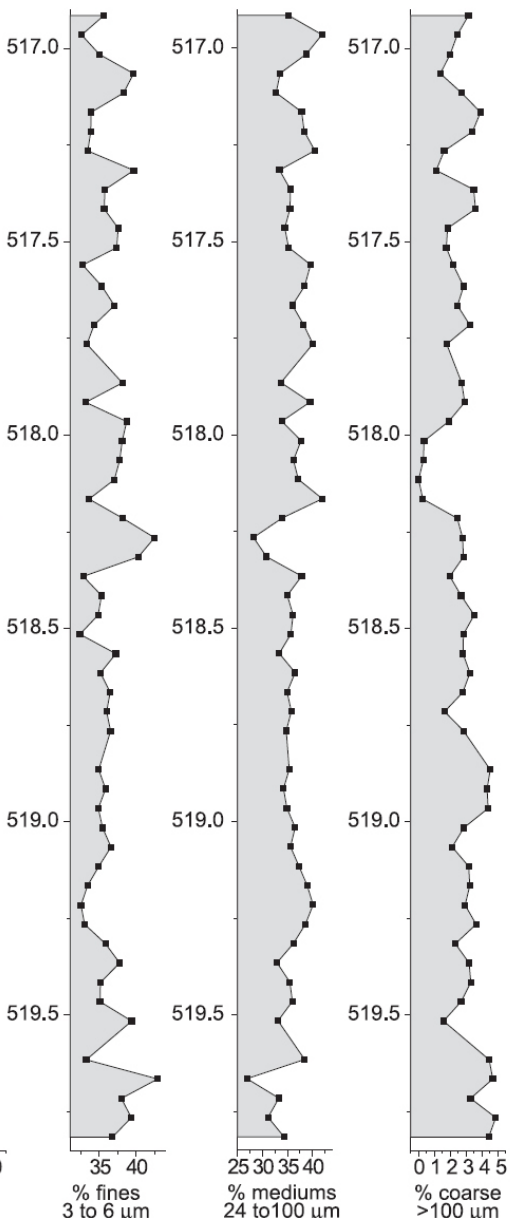

Fig. 4. Grain-size distribution in the examined interval. (a) Mean grain size, $\mu \mathrm{m}$; (b) median grain size, $\mu \mathrm{m}$; (c) mode, $\mu \mathrm{m}$; (d) sorting, $\phi$; (e) percent fines, 3- to 6- $\mu \mathrm{m}$ fraction; (f) percent intermediates, 24- to 100- $\mu \mathrm{m}$ fraction; (g) percent coarse, $100-\mu \mathrm{m}$ fraction. 
coarse fraction (dominantly radiolarians and sponge spicules) is less than $5 \%$ of the carbonate-free fraction (Figure 4g), decreases slightly upsection, and exhibits no cyclicity.

\subsubsection{Calcareous Nanofossils}

Calcareous nanofossil assemblages are dominated (60-78\%; average $72 \%$ ) by Coccolithus (predominantly C. pelagicus) and Toweius species (predominantly $T$. craticulus), with less abundant taxa that include Fasciculithus species (average 10\%), Zygrhablithus bijugatus (average 6\%), Sphenolithus species (predominantly S. primus; average $5 \%$ ), and Discoaster (predominantly $D$. multiradiatus; average $2 \%$ ).

Species diversity, as expressed by the Shannon Diversity Index $(\mathrm{H})$, varies significantly and systematically in relation to the sedimentary cycles. One of the components of $\mathrm{H}$, species richness $(S)$, is statistically similar throughout the studied interval. The second component of $\mathrm{H}$, evenness ( $E$ $=H / \ln S)$, varies systematically. Higher evenness values, equating to lower dominance by any taxa in the assemblage, correlate with magnetic susceptibility $(r=-0.464, p<0.0003)$, carbonate content $(r=0.506, p<0.0001)$, kaolinite $(r=-0.592, p$ $<0.0001)$, and color $(r=0.570, p<0.0001)$, indicating the strong tendency for darker sediment to contain assemblages dominated by few taxa.

Much of the variation in evenness is a function of changes in abundance of Coccolithus, as indicated by the strong negative correlation of this taxon with evenness $(r=-0.721, p<0.0001)$. Coccolithus dominates in most samples (average $46 \%$ ), but varies significantly (33-64\%). Abundances of Coccolithus correlate with color $(r=-0.461, p<0.0007)$, magnetic susceptibility $(r=0.372, p<0.004)$, and kaolinite $(r=0.511, p$ $<0.0001)$, indicating that Coccolithus has a tendency to be more abundant in the darker green, carbonate-poor beds. Discoaster correlates with evenness $(r=0.400, p<0.002)$ but not with any sedimentological variable. As noted above, Discoaster comprises only a small part of the assemblage, so that although it covaries with evenness, changes in its abundance do not contribute to evenness. These Blake Nose assemblages correlate well with the T. craticulus-C. pelagicus Assemblage of Haq and Lohmann (1976), which dominated the mid- to low latitudes during the late Paleocene. The paleoecological preferences of the dominant taxon (C. pelagicus) vary with time. C. pelagicus migrated latitudinally during the Paleogene, moving from a late Paleocene dominance only in low latitudes, to dominance in mid-tohigh latitudes only during the Eocene, to high abundance only in the high latitudes during the Oligocene (Haq and Lohmann, 1976). Thereafter, C. pelagicus has been an r-selected opportunist that was common or dominant in cooler, mesotrophic waters at high to mid-latitudes. The migration of $C$. pelagicus may have been due to a significant change in its ecological response through the Paleogene (Wei and Wise, 1990) or to a shift in meostrophic environments from low to high latitudes as ocean circulation became more strongly thermally driven. The distribution patterns of Paleogene Discoasters indicate that they were adapted generally to oligotrophic conditions (Aubry, 1992, 1998) with a clear preference for warm, low latitude surface waters (Bukry, 1973; Haq and Lohmann, 1976; Bralower, in press).

\subsection{Mass Accumulation Rates and Flux of Biogenic} and Terrigenous Components

Based on shipboard determination of the linear sedimentation rate for this interval $(18 \mathrm{~m} / \mathrm{my})$

Table 3

Range of mass accumulation rates for carbonate, silica, and terrigenous components, with average for green and white beds

\begin{tabular}{ccc}
\hline Component & $\begin{array}{l}\text { MAR based on } \\
\text { linear sed rate } \\
\text { of } 18 \mathrm{~m} / \mathrm{my} \\
\left(\mathrm{mg} / \mathrm{cm}^{2} \mathrm{ky}\right)\end{array}$ & $\begin{array}{l}\text { MAR based on } \\
\text { linear sed rate } \\
\text { of } 14 \mathrm{~m} / \mathrm{my} \\
\left(\mathrm{mg} / \mathrm{cm}^{2} \mathrm{ky}\right)\end{array}$ \\
\hline Carbonate & $1075-1530$ & $830-1190$ \\
Green beds & 1330 & 1030 \\
White beds & 1430 & 1110 \\
Silica & $13-280$ & $10-220$ \\
Green beds & 100 & 80 \\
White beds & 100 & 80 \\
Terrigenous & $1240-1770$ & $960-1375$ \\
Green beds & 1480 & 1150 \\
White beds & 1380 & 1070 \\
Fine $(<6 \mu \mathrm{m})$ & $450-620$ & $350-480$ \\
Green beds & 540 & 420 \\
White beds & 480 & 380 \\
Intermediate & $410-690$ & $315-530$ \\
$(24-100 \mu \mathrm{m})$ & & 410 \\
Green beds & 530 & 400 \\
White beds & 510 & \\
\hline
\end{tabular}


and shipboard determination of dry bulk densities of two samples from a comparable interval from Hole 1051A $\left(1.6 \mathrm{~g} / \mathrm{cm}^{3}\right)$, mass accumulation rates (MAR) were calculated for major components of the 26 samples for which silica content was determined. Terrigenous fluxes range from 1,240 to $1,770 \mathrm{mg} / \mathrm{cm}^{2} \mathrm{ky}$ and exceed carbonate fluxes which range from 1,075 to 1,530 $\mathrm{mg} / \mathrm{cm}^{2} \mathrm{ky}$ (Table 3 ). Terrigenous flux is significantly greater for green beds than for white beds. MARs for fine and intermediate terrigenous grain sizes are nearly identical and range from 410 to $690 \mathrm{mg} / \mathrm{cm}^{2} \mathrm{ky}$. Silica flux is the same in both green and white beds $\left(100 \mathrm{mg} / \mathrm{cm}^{2}\right.$ ky; Table 3).

\section{Discussion}

\subsection{Period of Sediment Cyclicity}

The only significant spectral power among the samples is a $27-\mathrm{cm}$ periodicity for carbonate, $\delta^{18} \mathrm{O}$ values, magnetic susceptibility, and kaolinite (Figure 3). A 27-cm periodicity is approximately an average of the spectral powers found by Norris and Röhl (1999) over a longer length of this core using iron intensity data. Based on an estimate of the number of cycles within chron C25n sediment, Norris and Röhl (1999) estimated that the duration of the cycles is $20-21 \mathrm{ky}$, close to the modern mean precession period that is an average of the 19- and 23-ky precession bands. Magnetic susceptibility values also indicate a power for $1.60 \mathrm{~m}$ (114,000 years) that is equal to the power for $27 \mathrm{~cm}$ (Figure 3). This value is not considered significant because it represents half the sampled length, a length insufficient to identify a cycle.

\subsection{Compositional Cause of Sediment Alternation}

The sedimentary component that accounts for the alternation in color is the iron mineral content as measured by magnetic susceptibility (Shipboard Scientific Party, 1998) and by iron intensity data (Norris and Röhl, 1999). Because it takes only a few parts per million for iron to color sediment, a small change in iron content produces beds of different color: green where iron is greater and carbonate content lower, and white where iron is lower and carbonate content higher. Accompanying an increase in iron con- tent is a tendency for a slight increase in kaolinite content. This increase is on the order of the analytical precision for X-ray diffraction. However, the 27-cm power of the kaolinite data, the significant negative correlation of kaolinite content with carbonate content, and the significant negative correlation of K/S ratios with carbonate content indicate that this small variation in kaolinite concentration between green and white beds is significant.

In addition, there are subtle but statistically significant cyclic changes in the nanofossil assemblages. The green beds have lower evenness values of the nanofossil assemblages with Coccolithus more dominant. This taxon is currently more abundant in mesotrophic and cooler waters. It appears that coccolith populations became more dominated by c. pelagicus during the times of slightly higher terrigenous input, possibly in response to increased nutrients brought in with the terrigenous sediment.

\subsection{Cause of Terrigenous Sediment Variation}

A slight variation in terrigenous sediment composition without a change in grain size would most likely be caused by eolian input. Wind patterns vary in response to precessional forcing. The MARs of the terrigenous components are closer to those estimated for eolian flux than for hemipelagic flux (Rea, 1994). Because eolian flux is approximately 1/100th of the hemipelagic flux, a slight change in the composition and amount of eolian debris could account for the small compositional difference between green and white beds.

\subsection{Climatic Implications of Sediment Alternation}

The alternation between green and white beds is accompanied by an alternation in stable oxygen isotopes, nanofossil assemblage evenness, kaolinite, and iron content. Although the $\delta^{18} \mathrm{O}$ values for the bulk sediment indicate colder temperatures during deposition of the white, more carbonate-rich beds, $\delta^{18} \mathrm{O}$ values more likely reflect diagenesis of carbonates on a cold seafloor, as Pearson et al. (2001) demonstrated for Late Cretaceous and Eocene marine sediment. Preservation of coccoliths is generally enhanced by a small amount of clay in the sediment, result- 
ing in less diagenesis for carbonate in the more clay-rich green beds. A greater degree of diagenesis beneath a cold seafloor would shift isotopes to lighter values and yield a colder temperature signal for the more carbonate-rich white beds, while less diagenesis would preserve the original (heavier) isotopes and yield an apparently warmer temperature signal for the more clayrich green beds. A similar phenomenon has been documented for Lower Cretaceous limestonemarlstone couplets by Frank et al. (1999).

The evenness values for the nanofossil assemblage and the variation in Coccolithus content between bed types suggest that the surface water over Blake Nose was mesotrophic and cooler during deposition of the green beds. During deposition of the white, carbonate-rich beds, surface waters were oligotrophic and warmer. This indicates that coccolith populations responded to variations in nutrient input. The increased nutrient input for coccoliths corresponded to increased eolian input of iron minerals during deposition of the green beds. Dust flux to the deep sea is higher during drier (except for hyperarid) climates (Pye, 1989; Rea, 1994). These indicate that green beds were deposited during drier and cooler climates. White beds were deposited during more humid and warmer climates.

The source area for eolian dust is most likely northwest Africa. Blake Nose has not moved latitudinally from its present position in the easterly wind belt (Shipboard Scientific Party, 1998), making it downwind from northwest Africa (Figure 5). Such a distal source area would ac-

a.

White Beds higher carbonate

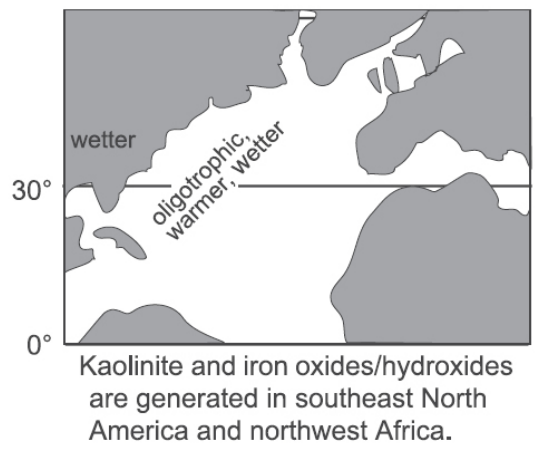

count for the lack of change in grain size between green and white beds. Rea (1994) demonstrated that beyond a transport distance of about $1,000 \mathrm{~km}$, grain size of eolian-transported dust reaches an equilibrium with the transporting winds and becomes constant. Goudie and Middleton (2001) reported that the sources of modern Saharan dust storms are dry lake beds that were fed by ephemeral streams during Pleistocene and Holocene pluvials. When the lakes dry up, winds deflate the lakebeds and transport the dust as far west as southeast North America and Venezuela. Maximum Saharan-sourced aerosol concentrations occur in July and August at Barbados and Miami (Goudie and Middleton, 2001). Clay mineral composition of Saharan dust varies with the latitude of the source area, with more kaolinite coming from the Sahel region closer to the equator (Goudie and Middleton, 2001).

If similar conditions of lake-filling during wet periods and deflation during dry periods operated during the Paleocene, then the green and white beds on Blake Nose indicate deposition that responded to alternations in aridity in northwest Africa. Kaolinite and iron minerals were produced and transported to lowlands during wet periods, but were eroded and delivered to the ocean during drier periods. Higher kaolinite contents in marine sediments are generally interpreted to indicate wet periods on adjacent continents (e.g., Chamley, 1989), but in our scenario, the slightly higher kaolinite contents, accompanied by higher iron content and no change in grain size, more likely indicate inb.

Green Beds higher kaolinite,mag. sus.

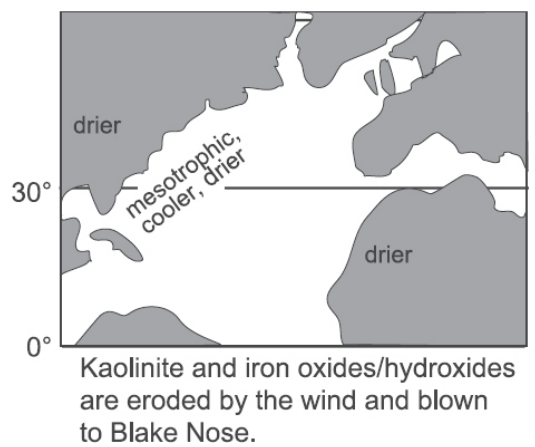

Fig. 5. Reconstructions of the southwest North Atlantic for the Paleocene. 
creased aridity in the eolian source area.

\subsection{Sedimentation Variation Under Precessional Forcing}

Kutzbach (1989) modeled precessional climate variation using a general circulation model to simulate atmospheric flow patterns and the hydrologic cycle. He reported that during precessional minima or perihelion summer (the opposite of our current configuration), there is an increased range of seasonal temperatures and in the intensity of summer and winter monsoon circulation. As a consequence, there would be more rainfall in northern Africa and drier conditions in the continental interiors at mid-latitudes. During perihelion summer, the Northern Hemisphere is tilted towards the sun when Earth is at its closest approach to the sun. The North Atlantic would be warmer during precessional minima, encouraging oligotrophic conditions over Blake Nose (Figure 6a), increased rainfall in northern Africa, genesis of kaolinite and iron minerals in soils, and deposition of the white beds at Blake Nose. At about 20,000 year intervals, the Earth would have summer at aphelion, with the Northern Hemisphere tilted away from the sun (Figure 6b). Cooler conditions would depress evaporation and rainfall, leading to aridity and a slightly increased supply of eolian dust to Blake Nose. Increased eolian flux and cooler surface water temperatures favored more mesotrophic conditions with attendant increased Coccolithus production.

\section{Summary and Conclusions}

Distinct color changes with a precessional periodicity in upper Paleocene sediment from Blake Nose in the northwest Atlantic are caused by subtle variations in the mineral composition of the sediment and not by dramatic alternation in carbonate or terrigenous input. An increase in iron oxide minerals of at most a few percent, as indicated by magnetic susceptibility and iron intensity data, accounts for the color change from white to green. The increase in iron mineral content is accompanied by a slight increase in kaolinite content and no change in grain size of the terrigenous sediment. A change in mineral composition without a change in grain size is likely caused by an increase in eolian flux, probably from northwest Africa. Higher carbonate, white sediment was deposited during periods when sea-surface temperatures over Blake Nose were warmer, as indicated by a higher nanofossil evenness index and lower Coccolithus in the carbonate-rich beds. During wet periods, kaolinite and iron oxides were generated in soils and/or transported to eolian source areas. Carbonate-poor, green sediment was deposited during cooler, drier periods, when the iron oxides and kaolinite that were generated during the wet period were eroded and transported by wind to Blake Nose. Kaolinite is generally assumed to indicate wetter and/or warmer climates, but this study demonstrates that kaolinite in marine sediment can also be an indicator of dry climate. Warm, wet periods that encouraged deposition of car- a.

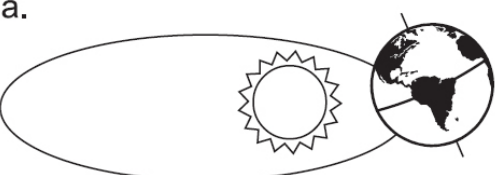

Northern summer at perihelion

b.

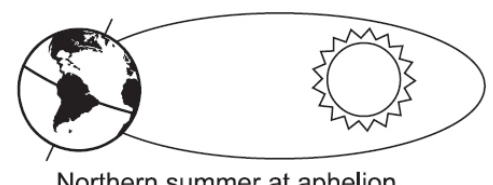

Warmer N.Atlantic SSTs

wetter

white beds

higher carbonate

lower kaolinite, Fe minerals

Cooler N.Atlantic SSTs

drier

green beds

lower carbonate

higher kaolinite, Fe minerals

Fig. 6. Precessional drive for alternating green and white beds at site 1051, Blake Nose, western North Atlantic. 
bonate-rich beds were possibly associated with perihelion summer or precessional minima conditions, and cooler, drier periods with aphelionsummer or precessional maxima conditions.

\section{Acknowledgements}

The following people helped with laboratory analysis and are here thanked for their hard work: Dana Packard (grain-size analysis, sample prep and XRD), David Walker (Si analysis, sample prep and XRD), and Brian Nicklen (sample preparation and XRD). Diane Winter identified and counted diatoms. The following people helped with suggestions for analyses to improve this study: Amy Leventer, Sheri Fritz, Lora Stevens and Rick Stumpf. This research used samples and data provided by the Ocean Drilling Program (ODP). The ODP is sponsored by the U.S. National Science Foundation (NSF) and participating countries under management of Joint Oceanographic Institutions (JOI), Funding for this research was provided by grants from the Joint Oceanographic Institutions U.S. Science Advisory Committee. We appreciate the efforts of two anonymous reviewers, whose comments substantially improved the manuscript.

\section{References}

Arthur, M. A., Dean, W. E., 1991. A holistic geochemical approach to cyclomania: examples from Cretaceous pelagic limestone sequences. In: Einsele, G., Ricken, W., Seilacher, A. (Eds.), Cycles and Events in Stratigraphy. Springer-Verlag, Berlin, pp. 126-166.

Aubry, M.-P., 1992. Late Paleogene nannoplankton evolution: a tale of climatic deterioration. In: Prothero, D. R., Berggren, W. A. (Eds.), Eocene-Oligocene Climatic and Biotic Evolution. Princeton Univ. Press, Princeton, NJ, pp. 272-309.

Aubry, M. P., 1998. Early Paleogene calcareous nannoplankton evolution; a tale of climatic amelioration. In: Aubry, M.-P., Spencer, G. L., Berggren, W. A. (Eds.), Late Paleocene-Early Eocene Climatic and Biotic Events in the Marine and Terrestrial Records. Columbia Univ. Press, New York, NY, pp. 158-203.

Behl, R. J., Tada, R., Irino, T., 2000. Late Quaternary textural change offshore of Point Conception, Site 1017, Central California Margin. In: Lyle, M., Koizumi, I., Richter, C., Moore Jr., T. C. (Eds.), ODP Proc., Sci. Results, vol. 167, pp. 255-261.

Biscaye,P.E., 1965. Mineralogy and sedimentation of Recent deep-sea clay in the Atlantic Ocean and adjacent seas and oceans. Geol. Soc. Am. Bull. 76, 803-832.
Bralower, T. J., 2002. Evidence of surface water oligotrophy during the Paleocene-Eocene thermal maximum: nannofossil assemblage data from Ocean Drilling Program Site 690, Maud Rise, Weddell Sea. Paleoceanography 17, 13.1-13.13.

Brown, G., Brindley, G. W., 1980. X-ray diffraction procedures for clay mineral identification. In: Brindley, G. W., Brown, G. (Eds.), Crystal Structures of Clay Minerals and their X-ray Identification. Monogr. London Mineral. Soc., vol. 5, pp. 305-360.

Bukry, D., 1973. Low-latitude coccolith biostratigraphic zonation. Init. Repts. DSDP 15, 685-703.

Chamley, H., 1989. Clay Sedimentology. Springer-Verlag, Berlin. 623 pp.

Chang, Y. M., 1967. Accuracy of fossil percentage estimation. J. Paleontol. 41, 500-502.

Conley, D. J., Shelske, C. L., 1993. Potential role of sponge spicules in influencing the silicon biogeochemistry of Florida lakes. Can. J. Fish Aquat. Sci. 50, 296-302.

Davis, J. C., 1986. Statistics and Data Analysis in Geology, 2nd ed. John Wiley \& Sons, New York. 646 pp. DeMaster, D. J., 1981. The supply and accumulation of silica in the marine environment. Geochim. Cosmochim. Acta 45, 1,715-1,732.

DeMaster, D. J., 1991. Measuring biogenic silica in marine sediments and suspended matter. Marine Particles: Analysis and Characterization. Geophys. Monogr. Am. Geophys. Union 63, 363-367.

Foucault, A., Mélières, F., 2000. Palaeoclimatic cyclicity in central Mediterranean Pliocene sediments: the mineralogical signal. Palaeogeogr. Palaeoclimatol. Palaeoecol. 158, 311-323.

Frank, T. D., Arthur, M. A., Dean, W. E., 1999. Diagenesis of Lower Cretaceous pelagic carbonates, North Atlantic: Paleoceanographic signals obscured. J. Foraminiferal Res. 29 (4), 340-351.

Haq, B. U., Lohmann, G. P., 1976. Early Cenozoic calcareous nannoplankton biogeography of the Atlantic Ocean. Mar. Micropaleontol. 1(2), 119-194.

Goudie, A. S., Middleton, N. J., 2001. Saharan dust storms: nature and consequences. Earth-Sci. Rev. 56, 179-204.

Jackson, M. L., 1969. Soil Chemical Analysis-Advanced Course, 2nd ed., pp. 127-152. Published by the author, Madison, WI.

Kuhn, G., Diekmann, B., 2002. Late Quaternary variability of the ocean circulation in the southeastern South Atlantic inferred from the terrigenous sediment record of a drift deposit in the southern Cape Basin (ODP Site 1089). Palaeogeogr. Palaeoclimatol. Palaeoecol. 182, 287-303. 
Kutzbach, J. E., 1989. Possible effects of orbital variations on past sources and transports of eolian material: estimates from general circulation model experiments. In: Leinen, M., Sarnthein, M. (Eds.), Paleoclimatology and Paleometeorology: Modern and Past Patterns of Global Atmospheric Transport. Kluwer Academic, Norwell, MA, pp. 513-521.

Liu, Z., Trentesaux, A., Clemens, S. C., Colin, C.,Wang, P., Huang, B., Boulay, S., 2003. Clay mineral assemblages in the northern South China Sea: implications for East Asian monsoon evolution over the past 2 million years. Mar. Geol. 201, 133-146.

Moore, D. M., Reynolds Jr., R. C., 1997. X-ray Diffraction and the Identification and Analysis of Clay Minerals, 2nd ed. Oxford Univ. Press, Oxford, 378 pp.

Mueller, G., Gastner, M., 1971. The "Karbonat-Bombe," a simple device for the determination of the carbonate content in sediments, soils, and other materials. Neues Jahrb. Mineral. Monatsh. 10, 466-469.

Norris, R.D., Röhl, U., 1999. Carbon cycling and chronology of climate warming during the Paleocene/ Eocene transition. Nature 401, 775-778.

Ogg, J. G., Bardot, L., 2000. Aptian through Eocene magneto-stratigraphic correlation of the Blake Nose transect. In: Kroon, D., Norris, R. D., Klaus, A. (Eds.), Proc. ODP, Sci. Results, vol. 171B, 1-58 [CDROM] and online: http://www. odp.tamu.edu/ publications/171B_SR/VOLUME/CHAPTERS/ SR171B08.PDF. (Leg 171B), Florida Continental Margin.

Pearson, P. N., Ditchfield, P. W., Singano, J., HarcourtBrown, K. G., Nicholas, C. J., Olsson, R. K., Shackleton, N. J., Hall, M. A., 2001. Warm tropical sea surface temperatures in the Late Cretaceous and Eocene epochs. Nature 413, 481-487.
Pollastro, R. M., 1982. A recommended procedure for the preparation of oriented clay-mineral specimens for X-ray diffraction analysis. Open-File Rep. U.S. Geol. Surv., pp. 71-82.

Pye, K., 1989. Processes of fine particle formation, dust source regions, and climatic changes. In: Leinen, M., Sarnthein, M. (Eds.), Paleoclimatology and Paleometeorology: Modern and Past Patterns of Global Atmospheric Transport. Kluwer Academic, Norwell, MA, pp. 3-30.

Rea, D. K., 1994. The paleoclimatic record provided by eolian deposition in the deep sea: the geologic history of wind. Rev. Geophys. 32, 159-195.

Röhl, U., Bralower, T. J., Norris, R. D., Wefer, G., 2000. New chronology for the late Paleocene thermal maximum and its environmental implications. Geology 28, 927-930.

Shipboard Scientific Party, 1998. Site 1051. In: Norris, R. D., Kroon, D., Klaus, A., et al. (Eds.), 1998. Ocean Drilling Program, Leg, Initial Rep., vol. 171B. Ocean Drilling Program, College Station, TX, pp. 171-239.

Waterhouse, H. K., 1995. High-resolution palynofacies investigation of Kimmeridgian sedimentary cycles. In: House, M. R., Gale, A.S. (Eds.), Orbital Forcing Timescales and Cyclostratigraphy-Spec. Publ. Geol. Soc. London 85, 75-114.

Wei, W., Wise Jr., S.W., 1990. Biogeographic gradients of middle Eocene-Oligocene calcareous nannoplankton in the South Atlantic Ocean. Palaeogeogr. Palaeoclimatol. Palaeoecol. 79, 29-61.

Wendler, J., Gräfe, K.-U., Willems, H., 2002. Reconstruction of mid-Cenomanian orbitally forced palaeoenvironmental changes based on calcareous dinoflagellate cysts. Palaeogeogr. Palaeoclimatol. Palaeoecol. 179, 19- 41. 